\title{
NATIONAL WATER RESOURCES ADMINISTRATION
}

\author{
JAMES W. FesLeR*
}

The federal government's relation to water resources is perplexingly complex. So commonplace has such an observation become that the truth it expresses may require revitalization by example. Take Monday, February 4, 1957, an ordinary day of proceedings in the United States Senate and House of Representatives.

Senator Ives introduced and explained a bill for construction of a hydroelectric power project at Niagara Falls by the New York State Power Authority. ${ }^{1}$ Senator Neuberger, from across the continent, introduced and spoke for a resolution proposing a Columbia River basin account, through which federal power revenues would help finance irrigation and reclamation projects. ${ }^{2}$ Senator Beall obtained unanimous consent to publish in the Congressional Record's appendix an editorial on pollution problems of the upper Potomac River. ${ }^{3}$ Senator Symington protested alleged neglect of Missouri in the administration of drought relief by Secretary of Agriculture Benson. ${ }^{4}$ The Senate adopted Senator Murray's joint resolution for a National Conservation Anniversary Commission to celebrate the fiftieth anniversary of the 1908 conservation conference of state governors called by President Theodore Roosevelt. ${ }^{5}$ Senator Carlson seized this opportunity to urge Senator Murray and his Committee on Interior and Insular Affairs to give favorable consideration to Senator Carlson's bill to establish a commission on the conservation, development, and use of renewable natural resources and particularly "problems of drought, decreasing water supply, and the wind erosion of our soil."

In the other wing of the Capitol, Representative Cooley explained for his Committee on Agriculture why the drought relief bill was delayed by objections of the Department of Agriculture, ${ }^{7}$ and Representatives Poage, Rogers, Hoffman, Fisher, Hays, and Christopher expressed sharply their disappointment at the delay. ${ }^{8}$ Representative Perkins addressed the House on the flood disaster in eastern Kentucky (and West Virginia, Virginia, and Tennessee).$^{9}$ The Board of Commissioners of the

* A.B. 1932, University of Minnesota; M.A. 1933, Ph.D. 1935, Harvard University; M.A. (hon.) r95I, Yale University. Alfred Cowles Professor of Govcrnment, Yale University, since r95I. Consultant, National Resources Planning Board, I935-4I; President's Committee on Administrative Management, 1936; United States Commission on Organization of the Executive Branch of the Government, 1948. Author, The Independence of State Regulatory Agencies (I942), Area and Administration (ig49); senior author, Industrial Mobilization for WaR (1947), The Fortr-Eight States: Their TAsks as Policy Makers and Administrators (1955); contributor, National Resources Committee, Reoronal Factors in National Planning and Development (1935).

1 I03 Cong. Rec. I290-9r (daily ed. Feb. 4, I957).

${ }^{2} I d$. at $1294-95$.

1 Id. at I30x-02.

Id. at 1295.

${ }^{\circ} I d$. at 13 ro.

${ }^{8} I d$. at $\mathrm{r} 335-39, \mathrm{r} 353-54$.

'Id. at I310-1 $x$.

${ }^{7} \mathrm{Id}$. at 1335 .

Id. at $1348-53$. 
District of Columbia submitted draft legislation authorizing it to construct two bridges over the Potomac River. ${ }^{10}$ The House Committee on Interior and Insular Affairs submitted a report on a bill to amend the Small Reclamation Projects Act of 1956. Bills were introduced for a fish hatchery, for return of certain lands to their former owners at the Buford Dam and Reservoir in Georgia, for appropiations for continued construction of the Calumet-Sag Channel in Illinois, for "certain works of improvement" in the Niagara River, for inclusion of "additional works of improvement" in the Watershed Protection and Flood Prevention Act, for congressional approval of a Great Lakes Basin Compact, and for preventing certain lake levels from dropping excessively because of the use of hydroelectric generators. ${ }^{12}$

Variety and complexity are at the heart of the problem of organizing for water resources administration. The observer feels as if he were looking into a steadily rotating kaleidoscope in which each mosaic pattern yields to another before the first can be fully registered on the consciousness. Partly for simplicity's sake, two possible ways of halting the rotation will be excluded from consideration here. One effort to weld variety into a patterned unity is the valley authority. Another is the proposal to devise a truly joint regional instrument of the states and the federal government. These will be assumed, without prejudice, to be unavailable as solutions on a nation-wide basis. Our concern, on this assumption, will be the organization of the federal government for its water resources responsibilities.

\section{I}

The Search for the Organizing Idea

Many official inquiries attest that the federal government is poorly organized for the development and execution of water resources programs. There is less agreement on what should be done. This is, in large part, because there is no consensus on a definition of the problem, and so on the starting point for organizational analysis. For organization is rational only as it relates to problems expressible in nonadministrative terms. Such problems, for example, might include agricultural production, government printing, children, labor, the South. Because so many problems clamor for governmental attention, only a few can be recognized as "organizing ideas" at the higher levels of organization. We cannot indefinitely multiply executive departments or even "independent establishments."

Selection of the most important organizing ideas is, therefore, mandatory. Such a selection is high policy, and so properly political. It may be done well or ill, by conscious choice or by indifferent acceptance of historical patterns. It will never be wholly satisfactory, for the concerns of government are too numerous and interrelated to fit neatly into ten or twenty or thirty tidy compartments. The organizational pattern may fail to settle which agency should have power finally to determine the contents and format of a government pamphlet on the children of migratory agricultural laborers in the South. But some problems, such as how much money the

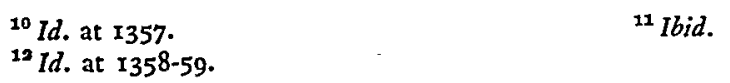


federal government should spend where on construction of what kinds of dams, may be so important to the public that these problems thrust themselves up into the level of important organizing ideas. Where we are in history helps to determine this agenda of major public concerns. Water resources, it is said, has now emerged as among the critical concerns of our time.

Whether "water resources" is the true organizing idea for the kinds of functions that should be grouped together administratively is not so clear as many assume. We need to have a clear statement of the problem to which administrative organization is meant to be responsive. There is no agreement on what that statement should be.

There are three principal ways of visualizing the nature of the problem. The first sees a single "whole"-water, for example-as the focus. The assumption is that if all executive agencies' functions related to this whole were brought together or otherwise harmonized, the problem would be solved. The second sees a process with distinct, and so separable, stages; planning, construction, operation would be illustrative in the water resources field. If each stage is unified, one need not worry so much about administrative unification of the whole process. The third sees legislative policy as the principal unifying or divisive element. The assumption is that if Congress would bring its policies, as embedded in statutes, into a consistent whole, we could abandon the emphasis upon administrative realignments.

Those who see a "whole" to which administration might be attuned do not agree on what that whole is. Yet, this needs to be settled, for it is the clue to determination of which functions and agencies need to be brought together organizationally.

One starting point might be water. At its simplest, this means water in the channel, with an emphasis on navigation, flood control, and fishing. But from this starting point, one quickly moves to recognition of the flow of the water to the land for irrigation and for water supply; and then the flow of water from the land, which raises questions of on-land measures to purify the flow by pollution control and to reduce the rate of flow and of siltation by forestation and other water-holding practices. This may all be considered an approach based on water-in-the-channel, though already land as it relates to water has come so clearly within the limits of the concept that what has been embraced has potentially startling administrative implications.

The shift to natural resources as a starting point for thinking about administration seems almost imperceptible. But water is no longer the touchstone for assertions of relevancy. Now water and land are seen so married by nature that "land-andwater" can be the focus. Subsoil mineral resources expand the focus further.

To move from either water or natural resources to the idea of a whole drainage basin introduces two new ways of visualizing the problem around which organization might be designed. First, it is an advanced step in the historical process marked by successive shifts from the single-purpose, single-dam approach, to the multiplepurpose designing of single dams by a single agency, and then to the multiple- 
purpose designing of single dams by collaboration among several agencies. We are, it appears, moving past the point when each dam, even if multiple-purpose in design, can be treated as an isolated project unrelated to upstream and downstream dams. But this interrelating of channel works is not the full realization of the basin concept. For the basin approach tends to absorb the land-and-water unity concept and to move on to the general resource base of the basin's economy.

Second, the basin concept introduces a new kind of "whole" into organizational thinking. The basin is an areal whole, as distinguished from "water" or "natural resources," which would be termed functional wholes. To attempt to organize around the idea of a series of areas such as basins introduces new problems of definition, for basins vary in size, have interrelations with neighboring basins, ${ }^{13}$ and are contributors to and beneficiaries of national and international policies and events.

Water, natural resources, and the basin concept may all be brought into a new focus-that of economic development. This, too, is a point that can be reached by so natural a progression that it hardly seems a distinctly different basis for administrative organization. Water, partly because of its fluid gold quality for agricultural development in the arid West, and partly because of its white coal quality as a yielder of hydroelectric power for industrial development in underdeveloped regions, acquires a strategic significance as a convenient lever with which to plan and effect economic growth. Yet, it is but one lever, and such other bases of economic development as thermal power, transportation facilities, mineral deposits, labor force, and research and education are factors demanding consideration in their own right.

Water seems a convenient taking-off point for analysis, policy-making, and administrative action pointed toward economic development. But there are alternatives that seem equally plausible. Water may carry one logically to hydroelectric power; hydroelectric power may carry one to some thermal power for "firming up" the hydroelectric power on those occasions during the year when the water flow cannot deliver energy at the peak level; from this, especially if hydroelectric power sites are exhausted and demand continues to increase, one may be carried to thermal power as the dominant energy source. The Tennessee Valley Authority has traversed this roạd leading away from the river. In 1950, hydroelectric plants produced ninety per cent of the system's power requirements; in 1956, steam plants produced seventytwo per cent of those requirements. ${ }^{14}$ Perhaps, then, energy sources, rather than

\footnotetext{
${ }^{23}$ Even the Tennessee Valley, so long an areal focus for resources development, does not stand alone. A former chairman of the board of the Tennessee Valley Authority writes: "The stream flow of the Tennessee accounts for some 25 per cent of the Ohio's discharge into the Mississippi. . . . On the lower Ohio and Mississsippi rivers this [TVA] system can reduce flood crests by $2 \frac{1}{2}-3$ feet, depending on the origin of the flood....

". . . . Half of its [TVA's] flood-control benefits accrue outside the Valley on the lower Ohio and lower Mississippi as far south as the mouth of the Red River." GoRDon R. CLAPP, THE TVA, AN Approsch to the Development of a Region 17, 86 (I955).

14 TVA ANN. REP. 3 (1956).
} 
water, are the key to economic development and, hence, the idea around which organization should be built. ${ }^{15}$

Economic development is sometimes equated with regional development. Yet, regional development has a specifically areal focus, while economic development (or economic planning) does not. Observe, for instance, the possibility that thinking so much of regional development of underdeveloped regions like the South and the West may lead to neglect of the relatively long-developed industrial East and Middle West. Here, the problems of out-migration of certain industries, in-migration of new elements for the labor force, accelerated urbanization, water supply, water pollution, shortage of recreational areas, and floods may call less for stimulation of economic development than for delicate adjustment of competing interests in an already welldeveloped economic and social complex. National considerations may well come to the fore, not excluding the national concern with the relative development or decline of the several regions of the country and, so far as national funds and energies are called upon, with the optimal disposition of these investments for promotion of the national interest. In such considerations, national defense may loom as large as will equitable balance in the development of regions. To organize for the making and execution of these major strategic decisions that impinge on regional development may then be thought the principal challenge to our administrative capacity.

Water, natural resources, the drainage basin, economic development-each is a possible focus for administrative organization. But public works are yet another alternative. The construction of dams, irrigation works, water-purification plants, and electric-transmission lines, seems the most obvious manifestation of governmental efforts to bring water into the service of the people. The construction of thermal power plants, highways, post offices, federal office buildings, hospitals, and other public buildings has potential significance for the economic condition of each region and of the nation at large. So much is this true that since early New Deal days (and even earlier), there has been recurrent effort to accumulate in good times a focus:

${ }^{15}$ The Report of the President's Materials Policy Commission chose energy resources as a coordinative

"The Commission is strongly of the opinion that the Nation's energy problem must be viewed in its entirety and not as a loose collection of independent pieces involving different sources and forms of energy. ...

"Ideally, the Nation should have a comprehensive energy policy and program which embraces all the narrower and more specific policies and programs relating to each type of energy and which welds these pieces together into a consistent and mutually supporting pattern with unified direction. ... [T]he multiple departments, bureaus, agencies and commissions which deal with separate energy problems must be less compartmentalized-more aware of the problems of coal vis-à-vis oil and gas; of waterpower as compared with lignite as a source of electricity; of the effects of pipeline regulation, for example, on oil imports from Venezuela. ...

“. . [A] comprehensive understanding can be achieved only if one central agency of the Government has clear responsibility for assaying trends and policies throughout the entire energy field. The scrutiny will be effective only to the extent that the same agency carries out the broad analysis required to appraise the various specific energy policies and programs for which today responsibility is scattered among a score of agencies." I President's Materials Policy Comm'N, Resources for Freedom 129, 130 (1952). Elsewhere, the same Commission starts from water, instead of energy resources, and urges "integrated action in each major drainage basin" and endorses the proposal of a board of review to appraise costs and benefits of proposed basin development projects. Id. at 55 . 
shelf of public works projects that can be quickly undertaken when a depression threatens. Note how swiftly the ground has shifted though. For now public works of all sorts are thought to warrant unified handling through central planning and activation. Add to this the appealing thought that if all the engineering talents of the government were in one department or bureau, there would be economies and a high esprit de corps, and one is well on the way to organizing around an idea that is wholly distinct from the other "organizing ideas" that have been reviewed.

Recapitulating, one way of visualizing the nature of the problem that we confront organizationally is to see a single whole that can serve as the focus for organization. Which whole we see matters a great deal, for a rational administrative structure must start from some premise about the nature of the substantive problem with which government is attempting to deal. Without seeking to develop any merely speculative hypotheses about the definition of the substantive problem, we have seen that, in fact, reasonable men define the problem quite differently. Some see water per se; some see land-and-water or natural resources as a kind of seamless web; some see economic development or planning (and that in such various guises as basin-based, regional, interregional, and national); and some see government as a great builder of physical structures-some on drainage systems, but others on land and unrelated to water or other resources.

It is common to assume that all functions related to a particular substantive problem of government should be brought together in a single agency. This has been implicit in what has been said to this point. But there are other ways of looking at organization than in this all-or-nothing way. One of the other ways, if we are thinking of water resources development, rests on a sharp distinction among planning, constructing, and operating the projects. Planning may be thought of as involving the selection of projects to be built (or recommending them to higher bodies for authorization and financing). This may turn on economic feasibility, engineering feasibility, relation to other developments on the river system and on land, indirect social benefits and costs, relative importance of other regions' proposals, and so on. It may also require a consideration of the multiple purposes of the project and an assurance that the project design serves these purposes in the proportions believed sound. It may as well be said immediately that "planning" so described becomes a rather mixed pot of technical research, highest-level economic and social planning, politics, and engineering design. This accounts for some confusion over how to organize for the planning function in the water resources field. But, despite this confusion, planning-all of which precedes the turning of a spadeful of earthcan be distinguished from construction.

Construction could be conceived of as simply an engineering task of building to specifications provided by the planners. Perhaps it becomes immaterial where the construction responsibility lies organizationally, so long as the specifications provided by the planning group are accepted as controlling.

Operation of completed projects can be regarded as what happens after the con- 
struction engineers have "delivered" the completed project. Under present conceptions of the relations among projects on the same drainage system, it can be argued that a single operating agency must control all dams on a particular drainage system, for the release of water upstream affects the flow of water into reservoirs downstream. The nature of this operating agency will be affected by the fact that operation is no merely mechanical, routine task, but involves a nice balancing of the competing claims of the multiple purposes for which the dam or system of dams was built. The volume and timing of water flow that is ideal for hydroelectric power production may not be ideal for navigation, flood control, irrigation, or other purposes. A single water master is needed, and his role will be more than a merely technical one. Yet, this is no argument for unification of land and water operations. As Charles McKinley has persuasively indicated, what needs to be treated as a unity for planning purposes need not be treated as a unity for operating purposes. ${ }^{16}$

The main point to be made is that planning-construction-operation can be thought of as a chain with weak links. So regarded, the argument that all three stages of water-related activities must be oganizationally united loses its prima facie validity. Instead, a wholly new way of looking at the organizational problem has been developed.

The third principal way of defining the problem is to see it as really a congressional problem. A recurrent theme in much of the official and professional literature of water resources administration is that the policies of Congress, as set forth in statutes, are inconsistent; that Congress has so organized its committee structure as to abet organizational confusion in the executive branch of the government; and that Congress encourages the project-by-project approach at the expense of comprehensive basin-wide or nation-wide programming. It is doubtful that any responsible student of the subject would care to question the factual accuracy of this theme, which a congressional subcommittee has put in these terms: ${ }^{17}$

Your subcommittee is convinced that, for the maximum economic return from Federal water resource developments, a single integrated plan must be developed and provided for each stream. It is of the opinion that the processing of unintegrated segments through different committees and the ultimate enactment of conflicting projects can lead only to waste and a chaotic situation. It believes that no segment of a plan should be approved by any committee or enacted by Congress so long as major conflicts exist between such segment and the parts properly under jurisdiction of some other element of the executive branch. The insistence of Congress upon coordination through its refusal to authorize conflicting elements would probably bring about the necessary coordination more quickly than any amount of reorganization. The agencies of the executive branch must be shown that they cannot attain their conflicting ends by playing one committee of Congress against another.

....

On the question of organization, then, the subcommittee is of the opinion that present

${ }^{16}$ MeKinley, The Valley Authority and Its Alternatives, 44 AM. PoL. Sci. Rev. 618 (1950).

17 Subcommittee to Study Civil Works of the House Committee on Public Works, The Civil Functions Program of the Corps of Engineers, United States Army, 82d Cong., 2d Sess. 38, 39 (1952). 
problems would not be solved in any marked degree by simple reorganization or by the establishment of a special board of review.

No serious student would fail to support efforts by Congress to improve its own relation to water resources problems. But what is in doubt is whether, absent remedial congressional action, one can or should attempt nothing to improve administrative organization.

To be sure, separate administrative agencies are allied with separate congressional committees, separate interest groups, and separate policies. But to think of these agencies as wholly passive elements in this pattern may be naive; indeed, the subcommittee itself recognizes this. ${ }^{18}$ If, of the four elements in alliance, the executive agencies are the element most readily altered, then there is a probability that significant organizational changes among the agencies would break up the prior alliances, induce a reforming of congressional committee structure, and sharpen awareness of policy inconsistencies.

\section{II}

\section{Official Proposals, I949-53}

Review of the official recommendations that have streamed from the Government Printing Office presses in the last decade is the most efficient way of perceiving the alternative organizational solutions that have appealed to thoughtful men who are not insensitive to the tension between the "one best way" (though they differ on what it is) and the political limits of tolerance. A convenient watershed for such a review is the inauguration of President Eisenhower in January 1953. In the Truman period, water resources organization was examined by the first Hoover Commission, the President's Water Resources Policy Commission, and the Missouri Basin Survey Commission, reporting, respectively, in 1949, I950, and early 1953. In the Eisenhower period, there have been the Temple University Survey, the second Hoover Commission, and the Presidential Advisory Committee on Water Resources Policy. The first reported in 1953 and the last two in I955.

The first Commission on Organization of the Executive Branch of the Government, chaired by former President Hoover, proposed that the Department of the Interior have a clear mission of "development of subsoil and water resources" and, arguing from the fact that such development required large public works, con-

${ }^{28}$ The subcommittee added its opinion that "if Congress were to establish clearly four elements of policy, much of the apparent need for reorganization and for establishment of a review board would cease to exist. These four elements are ( $I$ ) phases in water-resource development for which the Federal Government should assume some responsibility and some measure of the degree of that responsibility, (2) the place of local and State interests in the Federal development of water resources, (3) uniform standards for use by the executive branch for the measurement of the economic justification of water resource development projects, and (4) uniform standards for the allocation of costs in multiple-purpose projects and uniform criteria for the establishment of rates for the sale of products to recover such costs." Id. at 39.

Admirable as it would be to have these policy elements clarified, it seems most doubtful that such clarification would make the need for reorganization vanish. 
cluded that the Department should manage other public works as well. ${ }^{10}$ This would bring together, in a Water Development and Use Service in the Interior Department, the rivers and harbors and the flood-control functions hitherto performed by the Army Corps of Engineers alongside the reclamation and power activities already in the Department. ${ }^{20}$ The other principal "Services" in the Department would concern themselves with Building Construction, Mineral Resources, and Recreation. ${ }^{21}$ The land-management work of the Department would be transferred to the Department of Agriculture; certain other transfers would remove units incompatible with the new concept of the Department. ${ }^{22}$ The Commission recognized that the Department of Agriculture would have an interest in the selection of irrigation projects, that the Department of State would appropriately handle international negotiations, and that the Federal Power Commission would continue to have concerns tangential to the water development and use functions of the Interior Department. ${ }^{23}$ These interdepartmental concerns are hardly the reason, though, for the Commission's recommending that there be in the President's office a Board of Impartial Analysis for Engineering and Architectural Projects, composed of "five members of outstanding abilities in this field." The Board would "review and report to the President and the Congress on the public and economic value of project proposals by the Department" and "periodically review authorized projects and advise as to progress or discontinuance." ${ }^{.4}$ Finally, the Commission proposed that each major drainage area have a Drainage Area Advisory Commission consisting of representatives of the Department of the Interior, the Department of Agriculture, and each state. ${ }^{25}$

This sets the stage well for much that was to emerge from the deliberations of subsequent official study commissions. Note the several elements here displayed. First, the Commission proposed to bring the civil work of the Corps of Engineers into the Interior Department, thus simultaneously bringing to a focus, within a single department, both the principal water or river activities of the Government and the principal dam-construction work of the Government. These are related, of course, but it is of some organizational significance to clarify which is the conceptual basis for thus joining what history and politics have thrust asunder. Second, it proposed to bring other major construction work into the Interior Departmentparticularly public buildings construction - on the excuse that as long as engineers for construction of dams and irrigation systems were being gathered together in the

\footnotetext{
${ }^{10}$ U.S. Comm'n on Org.inization of the Executive Branch of the Government, Reorganization of the Department of the INterior I (1949).

${ }^{20}$ Sen. John C. McClcllan and Rep. Carter Manasco, members of the Commission, dissented and filed a spirited defense of the Corps of Engineers. Id. at $8 \mathrm{r}-89$.

${ }^{21}$ Id. at 15 et seq.

${ }^{22} \mathrm{Id}$. at $7 \mathrm{et} \mathrm{seq}$.

${ }^{23}$ Id. at 38 . On the Federal Power Commission, the report was not entirely clear, but proposed "a study as to separation of certain general survey activities from the Federal Power Commission and their inclusion in this Department." Id. at 15.

24 Id. at $2-4$.

${ }^{25}$ Id. at 38 .
} 
Department, the Government's engineers working on dry land might as well come along too.

Third, the Commission proposed a board of review at the presidential level. The most clear-cut rationale for the recommendation was that "there is no adequate check in the Government upon the validity or timing of development projects and their relation to the economy of the country."26 Elsewhere, one of the jobs of the Board is described as that of assuring that the Department of Agriculture gets a chance to examine Interior Department proposals for irrigation and reclamation projects. ${ }^{27}$ These are distinct, even if not inconsistent, concepts of the Board's role, and it is useful to keep them clear. The Board was proposed even though, as a result of interdepartmental transfers of functions, most project proposals would be initiated by the Interior Department; a question left unanswered is why the Interior Department should not be expected to do the assessment job instead of having to pass the projects on up for a second going-over at the President's level. It is quite a different thing to work from the assumption of scattered and competing points in the federal bureaucracy for initiation of project proposals, with no hierarchical superior to these initiating points save the President. On that assumption (characteristic of some of the later survey commissions), a case can be made for a review board to do much of the President's project-review work for him. A further feature of the Commission's proposed Board of Review needs to be noted. The Board members were not to be representatives of the several concerned federal departments, but rather, if the Commission's Task Force on Public Works were to have its way, of "the seagreen incorruptibles of the engineering profession."28

Fourth, the Commission recognized the drainage basin concept of water development and the desirability of in-the-basin organization for collaboration among interested agencies and governments. Indeed, one of the more interesting passages in the report is one reading, "A further reason for unified organization of water development agencies [in the Department at Washington] is to permit the determination of policies upon a watershed basis."29 The Commission quotes with approval the advocacy by its Task Force on Natural Resources of "regional decentralization of the Water Development Service ... by river basins where practicable, to facilitate 'grass roots' decisions, interservice cooperation, and local participation in planning...."30 But then, in recommending a series of Drainage Area Advisory Commissions, the Hoover Commission makes clear that their purpose "should be coordinating and advisory, not administrative." ${ }^{\text {31 }}$

These four ideas-the consolidation of water resources activities in one department (which would also have mineral resources, but not public lands), the consolidation of construction engineering in one department, the review of water resources project proposals at the presidential level by a special board, and the drainage basin as a unit

${ }^{20} I d$, at 2.

${ }^{28} I d$. at 6.

so Id. at 37 .
${ }^{27} I d$. at 39.

${ }^{29} \mathrm{Id}$. at 36 .

${ }^{31} I d$. at 38 . 
for planning, cooperation, and advice (if not for administration)-are the pegs for much of the subsequent thinking about water resources administration.

What is missing from this agenda is the idea that found expression in the dissenting report of a distinguished minority of the first Hoover Commission. Commissioners Dean Acheson, James K. Pollock (a leading political scientist), and James Rowe (a former Assistant to the President) recommended establishment of a Department of Natural Resources. In their eloquent statement, the three dissenters argue from a conviction that "the conservation, development, and use of [all] our public resources is a single indivisible problem," and that forests, water, public lands, minerals, wildlife, fisheries, recreation, and power are but parts of that single problem. The Department they propose would include approximately the same functions as those favored by the Commission majority for the Department of the Interior, with two principal differences: (I) a Forest and Range Service would be created to include the Forest Service and forest insects and disease research (by transfer from the Department of Agriculture), and the Interior Department's Bureau of Land Management (which the majority had proposed to shift to Agriculture); and (2) public building construction work would not be brought into the Department. The dissenters concur substantially with the majority on the need for a Board of Review in the President's office and go beyond the majority in welcoming the regional authority device for "some river basins."32

Some of the points made in the minority report require examination, for they add to the dimensions in which we may think about the organizational problem. It is already clear that two key propositions of the minority are, first, that land-and-water (and minerals) is the problem, and second, that government should be administratively organized to give strength to "major purposes." Both propositions lead to the proposal of a Department that encompasses all natural resources and emphasizes resources development in the public interest as the major departmental purpose. The second proposition explains why the minority prefer that construction unrelated to resources development be left to other departments having other major purposes. A curiosity in the minority's logic, however, is that they wind up not really meaning what they certainly appear to say. What they do mean is that public lands should be under the aegis of the department that has water resource development functions. Private lands, they grant, belong with the Department of Agriculture, which might well "focus its responsibility on harmonizing the producer interest in private lands with the need for conservation of . . . soil resources." ${ }^{\text {s3 }}$ So, oddly, what we have is a division of jurisdiction in terms of public and private ownership of land-not in terms of the unity of land and water. Furthermore, because almost all of the public lands are located west of the one hundredth meridian, the minority are implying unity of western land and water, but disunity of eastern land and water-a point that was never made explicit.

The President's Water Resources Policy Commission, chaired by Morris L. Cooke,

${ }^{82}$ Id. at 54,68 .

${ }^{33}$ Id. at 79 . 
reported in December 1950. Although requested by President Truman to steer clear of questions of administrative organization and focus on policy matters, the Commission could not escape the interrelations of policy and administration. It allied itself with the Acheson-Rowe-Pollock minority of the Hoover Commission, in favor of a Department of Natural Resources, with a decentralized Water Development Service through which basin development programs would be planned and managed. $^{34}$ But as the Hoover Commission's reports had been before the President and Congress for a year and a half without action being taken to unify water resources activities, the Cooke Commission considered what might be done in absence of such action. It chose to advocate congressional approval of interagency drainage basin commissions, each to include equal representation from all federal agencies with functions included in water resources programs, and each to be presided over by an independent chairman appointed by and responsible to the President. A Federal Board of Review would be created in the executive branch and be composed of members "with a broad understanding of the economic and social as well as the technical aspects of regional development." ${ }^{35}$ The Commission recognized, as an alternative to the basin commissions, the creation of regional or valley administrations to manage the water and related land resources of the several basins.

More than most investigating groups, the Cooke Commission derived its organizational conclusions from immersion in the substantive problems of water resources and from an analysis of how the planning and development processes should be designed. It was not the first or the last group to find that gross inconsistencies in congressional policies and standards applicable to different types of projects and agencies were at the root of much of the difficulty. This being the case, mere organizational shuffings are not likely to be effective remedies. And yet, using existing organizational units as building blocks, it may be possible to introduce combinations and juxtapositions that will introduce more order than that of a jumbled pile. And it may be possible to design processes by which questions will be posed to Congress for decision that preclude Congress' escaping the responsibility for effecting reconciliation of its own several policies.

The heart of the matter, as the Cooke Commission saw it, was a basin program of a comprehensive, multiple-purpose type that would be related to the prospective economic and social development of the region, as a factor in the growth of the nation. The tool for destroying separatistic approaches by the several national agencies was to be appropriations. "At each step in the planning, authorization, and appropriation process," the Commission said, ${ }^{36}$

... the basin program should be treated as a single program for all purposes rather than as an aggregate of plans for separate purposes to be individually approved. This procedure should replace the diverse authorization process now followed by the Federal agencies.

34 X President's Water Resources Policy Comm'n, Report 49 (I950).

35 Ibid.

${ }^{30}$ I id. at 52. 
Appropriations should therefore be made to the basin programs as a whole, on the basis of budgets showing the approximate amounts to be allocated to the specific projects and participating agencies, rather than to specific functions.

All projects and programs recommended by the basin commissions would be analyzed and reviewed by the proposed Board of Review with an eye to economic feasibility, the broad national interest, and possible modifications in the public interest. ${ }^{37}$

Were the procedures to be adopted along with the Commission's organizational proposals, a substantial shift in administrative power would be probable. The projection of the President into the basin commission, through the independent chairman, together with the principle of equal representation of all agencies with functions included in water resources programs, might lead to more fully integrated basin programs than emerge from, say, interagency committees chaired by the Corps of Engineers and operating on the absolute veto principle. The independent chairman and the minor-interest representatives (from the Forest Service, National Park Service, Fish and Wildlife Service, and Public Health Service, among others) might be expected to reject such self-serving propositions as the primary combatants-the Corps of Engineers and Bureau of Reclamation ${ }^{38}$-might advance. The fact that agencies would be able to approach Congress for planning and survey money, for authorization of projects, and for appropriations for projects only through each basin commission would reduce the mutual re-enforcement of fragmentation currently typical of relations between agencies and congressional committees. The system would probably occasion a recasting of the congressional committee system in the water resources field, though the Cooke Commission was careful to avoid saying so.

The recommended Board of Review, although it appears patterned after the Hoover Commission proposal, has, in fact, a rather different role. It would review basin programs primarily to assure their compatibility with the larger concerns of the nation, which necessarily includes a consideration of the relations among programs of the several basins. In other words, its role would be less that of achieving coordination among the national agencies concerned with water resources than that of seeing to it that regionally-oriented basin commissions did not let their local enthusiasms blind them to the larger national interest in defense, maintenance of a national and world market, and balanced development of the national economy.

Early in 1952, President Truman established the Missouri Basin Survey Commission, under James E. Lawrence's chairmanship, to "study the land and water resources of the Missouri River Basin and ... related matters ... and ... prepare recommendations with respect to an integrated and comprehensive program of development, use, and protection of said resources." ${ }^{30}$ Just before the expiration of President Truman's term in January 1953, the Commission submitted its report, Missouri: Land and Water. The eleven-member Survey Commission, with three members

${ }^{37} \mathrm{I}$ id. at 53 .

${ }^{38}$ The Soil Conservation Service seems too newly active to be a "primary combatant," but too ambitiously involved in watershed projects to loom as merely a minor interest.

${ }^{30}$ Quoted in Missouri Basin Survey Comm'n, Missouri: LaNd and Water 25 (1953). 
dissenting, proposed that Congress establish a Missouri Basin Commission of five full-time members, to be appointed by the President with the consent of the Senate, from residents of the basin, belonging to both political parties. ${ }^{40}$ There are ambiguities in the statement of the Commission's purposes and powers, but the terms used are as follows. The general purpose is $:^{41}$

... to prepare and direct the development of a land and water resource program for the Missouri Basin. It will be the Commission's task to harmonize and reconcile the interrelated features and purposes of such a program by directing and coordinating the activities of all Federal agencies relating to resource development. [italics added]

The proposed Commission would review all uncompleted investigations, plans, programs, and projects of each federal agency, even if they were approved or authorized by Congress prior to establishment of the Commission; and all future investigations, examinations, and surveys would be directed by the Commission, which sometimes would direct agencies to conduct joint studies of these types. Requests from agencies for authorization of completed project plans would have to be submitted to the Commission for analysis of engineering and economic feasibility and relation to the basin programs; and the request, accompanied by the Commission's report and recommendations, would then go to Congress "through the established channels of review in the Executive Office of the President." would be unable to issue any permit or license if the Missouri Basin Commission, to which the application would have to be referred, held it inconsistent with the basin program.

Annually, the Commission would prepare "a consolidated Basin Resource Budget for land and water resource development, in consultation with the operating agencies," including budgets for basic data, planning, construction, and operation, and indicating three alternate levels of expenditure "for the guidance of Congress in appropriating funds for resource development." ${ }^{33}$

The difficulty in defining the role of the Commission lay in the fact that, in contrast to the situation of the Tennessee Valley in 1933, the Missouri Valley is already in process of resources development through construction programs of federal agencies. Rejecting the "authority" idea, the Lawrence Commission sought to devise "a basin agency responsible for directing and coordinating the special skills and competences of the existing Federal agencies in a unified program of resource development"-that is, "an organization which would not replace the Federal agencies, but would direct and coordinate their activities." ${ }^{\text {44 }}$ Yet, a line is attempted between the construction activities, which are left to individual agencies (under the Commission's guidance), and the operation of the completed structures. In the latter phase, the Commission "is given the responsibility for integrated operation of the main stem

\footnotetext{
${ }^{10} I d$. at 264 . The Commission split on exactly how the states should be related to the new organization. The majority proposed an advisory committee of governors.

${ }^{11} I d$. at 8. See also id. at 265 . ${ }^{12} I d$. at 265.

${ }^{43}$ Ibid.

4Id. at 9, Ir.
} 
and tributary reservoirs for water control and power generation and dispatching." ${ }^{\text {"45 }}$

Missouri: Land and Water contains a perceptive and enlightening review of the organization problem as it existed in the basin at the time. Specific experiences are described, and the existing coordination devices are carefully appraised. ${ }^{40}$ But, save as the inadequacy of existing arrangements is sufficient proof that anything else will be better, the rationale for the Commission's proposed organization is nowhere clearly stated. It is difficult to visualize the Missouri Basin Commission, with its principal offices in the basin, coordinating, advising, guiding, directing, and establishing "operational goals and administrative policy"47 for the field officials of the national functional agencies. As Hubert Marshall has pointed out, the role proposed for the new Commission $^{48}$

... would create a schizophrenic situation in which operating officials recruited by and responsible to bureau chiefs in Washington, would at the same time be working under the immediate supervision of the commission. ... [T] here is every reason to suppose that the operating bureaus, if allowed to remain in the basin, would not readily abdicate their control of policy and program to a new commission.

Yet, in its very failure to face such problems the Lawrence Commission serves for us the function of accenting the difficulty and, hopefully, forcing a clarification. How can an area-based agency be related to national function-based agencies?

\section{III}

\section{Offictal Proposals, 1953-55}

In late 1952, preparatory to the inauguration of Dwight D. Eisenhower as President, a study was undertaken "in order to bring the Hoover Report up to date and prepare guidelines for continued reorganization in the new Administration." ${ }^{40}$ While not an official study in the usual sense, it was designed to facilitate the work of the incoming Administration, and, in fact, it fed directly into the President's Advisory Committee on Government Organization that was established under Nelson A. Rockefeller immediately after the inauguration. ${ }^{50}$ This, the Temple University Survey of Federal Reorganization, proposed that the Interior Department have a Water Development Service that would include "the civil functions of the Army Corps of Engineers; the functions of the Bureau of Reclamation; all flood-control functions of the Department of Agriculture which consist of actual engineering as distinct from counseling in farming practices"; and certain other responsibilities. ${ }^{61}$ The Interior Department would also contain a Power Service comprised of the Bonneville, Southwestern, and Southeastern Power Administrations and certain planning authorities vested in the Federal Power Commission. A Minerals Service would complete the principal large blocks of the Interior Department's structure, but the

45 Id. at $\mathrm{II}$-I2.

${ }^{16}$ Id. at $213-46$.

${ }^{47} I d$. at 266.

${ }^{48}$ Hubert Marshall, Organizing for River Basin Development, 13 Pü. AdmIn. Rev. 273 (1953).

${ }^{40}$ I TeMple University, SURVeY OF FederAl Reorganization preface (1953).

${ }^{80}$ Exec. Order No. 10432, I8 Fed. Reg. 617 (1953), 5 U.S.C. \$133z (Supp. III, 1956).

${ }^{11} 2$ TEMPLE UNIVERSITY, op. cit. supra note $49 \mathrm{I}$, at 34 . 
National Park Service and Fish and Wildlife Service would also continue. The Bureau of Land Management would be transferred to the Department of Agriculture. Finally, the planning of water resources development would be decentralized through establishment of "State-Federal inter-agency regional committees operating under the leadership of field representatives of the Division of Water Resources Programming."

Curiously, these recommendations do not flow naturally from the analysis the study group set on paper. The non sequitur is simply that from the premise that "all our natural resources are inextricably inter-related,"53 the group concludes that the Interior Department should have water and mineral resources and parks, and the Department of Agriculture should have land resources, including public lands, soil, and forests. Note this statement of the problem of the Department of the Interior: ${ }^{54}$

The main effort of this Department is addressed to the development and conservation of the nation's water, land and forest resources. Yet, for all its size, Interior preseritly encompasses a comparatively small portion of federal activities in these areas. And that, with respect to the Department of the Interior-and the nation-is the problem.

Or the following passages: $:^{55}$

Careful study . . . shows that the leadership and impetus required to administer federal resources activities with due regard for their importance to the national welfare requires that a single Cabinet Department be devoted to the main purpose of wise conservation and development of the nation's resources. [italics added]

-...

Reorganization of the federal natural resources functions should provide a means for achieving a proper balance among the various Federally-supported resources programs which, in the past, have been weighted heavily in favor of river development.

Yet, the burden of the recommendations made is that land resources should be in a different department from water resources! The explanation given for this, inconsistent, of course, with earlier expressions, is that the most important use of land (including the public domain) is the production of food and fiber crops, which is already the concern of the Department of Agriculture, as are also forestry, soil conservation, and grazing. ${ }^{\text {E6 }}$

The recommendation for absorption of the civil functions of the Army Corps of Engineers by the Interior Department rests on familiar grounds: that "there cannot logically be two plans for one river," and that "every effort at voluntary cooperation has failed." Wh Which way the consolidation tide should run seems clear, for logic cannot support the conduct of large-scale operations of a purely civilian nature by any branch of the Armed Services.

The Temple University study, however, was the last official study to recommend a transfer of the civil functions of the Army Corps of Engineers. From r953 on, the

$\mathrm{CI}_{2} \mathrm{id}$. at 35.
$\mathrm{Bs}_{2}$ id. at $3 \mathrm{I}$.
$\mathrm{Bd}_{2} \mathrm{id}$. at 29.

${ }^{55} 2$ id. at 30 .

${ }^{56} 2$ id. at 36 .

${ }^{57} 2$ id. at 35 . 
Corps was to be treated as an immovable object against which no irresistible force could be effectively mobilized. Politics makes strange river-bedfellows.

The second Hoover Commission, reporting in I955, had given particular attention to problems of water resources and power. According to Commissioner Chet Holifield, $\$ 430,000$ was spent on the Commission's inquiry into these problems; ${ }^{68}$ this was almost a sixth of total Commission expenditures. Eschewing the first Hoover Commission's strong advocacy of a shift to the Interior Department of the civil functions of the Corps of Engineers, the second Commission simply recommended (a) strengthening of the Bureau of the Budget's staff to "enable it to fully perform the function of evaluation of the merits of water development projects presented to it for appropriations,"59 and (b) creation of a Water Resources Board in the Executive Office of the President. This Board would include some Cabinet members, five public members, and "a non-Government chairman." The Board's public members were to be chosen from "engineers, economists, and others of recognized abilities." The Board would have two functions: (a) "to determine the broad policies for recommendation to the President, and, with his approval, to the Congress," and (b) "to devise methods of coordination of plans and actions of the agencies both at the Washington level and in the field."

This, it would appear, is an abdication of the Commission's responsibility to find an answer to the administrative evils it describes. A content analysis of the Commission's report would reveal its awareness of these evils: "overlaps and conflicts between Federal agencies"; "when the control of reservoirs in the same river is under different agencies with different responsibilities and motivations there is inevitable conflict in point of view"; "the diffusion of authority among the agencies on water development, and the need for clarification and coordination"; "flood control is not an isolated administrative segment of our water development. It involves great problems of coordination between Federal agencies engaged in water development." ${ }^{102}$

The Commission's report does devote attention to river basin coordination, although this yielded no formal Commission recommendation. "With some exceptions," the report reads, "the critical place for coordination of water development projects is at the river-basin level." It then harks back to a r926 speech by then Secretary of Commerce Hoover proposing that each river basin have a commission to coordinate development and to consist of representatives of each state and major federal agency concerned, and of "the private development agencies." ${ }^{3}$ After tracing this idea through the reports of intervening study commissions and legislation, the Hoover Commission declares that the proposed Federal Water Resources Board "would set up such basin commissions to represent fairly the Federal, State, and private interests." They would not be administrative bodies, nor would they neces-

${ }^{89} 2$ U.S. Conm'n on Organization of the Executive Branch of the Government, Report to (x955).

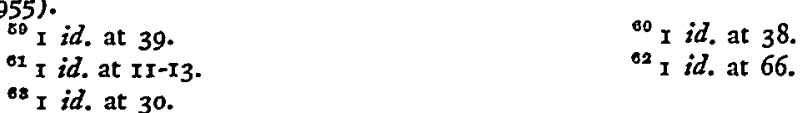


sarily include all streams in a particular drainage area; further, "they should be varied in scope and purpose with changing economic, social, or political conditions" (a welcome thought thirty years after the Secretary of Commerce set forth the model). In distinctive prose, the Commission states, "Their function would be limited to plans, coordination of projects in each particular basin, and to coordinate between basins where such interests overlap." 64

This proposal for basin commissions, vague as it is, must somehow be reconciled with the clear-cut recommendation for incorporation, as public enterprises, of the Columbia River basin system, the Hoover-Parker-Davis Dams Administration, the Central Valley Project of California, the Missouri River basin project, the Southwestern Power Administration, and the Southeastern Power Administration. ${ }^{65}$ This is coupled with recommendation that these to-be-corporations and the Tennessee Valley Authority be required to secure their capital for future improvements, when authorized by Congress, by issuing their own securities to the public. The purpose of the two recommendations together is "to release the Federal Government of further call upon the taxpayers to finance the seven major Federal power organizations." ${ }^{\text {"B }}$ A plausible reconciliation would be that the basin-commission proposal is pointed toward the planning of projects and the incorporation proposal toward the operation of power production and sale from the constructed projects. But this fails to square with the expectation that the incorporated enterprises would be proposing "future improvements" to Congress.

The treatment of the civil functions of the Corps of Engineers is one of the more curious aspects of the Hoover Commission's report. It is worth examining, for it marks abandonment of the consolidation emphasis of previous reports. The Commission cites chapter and verse of errors in cost estimates by the Bureau of Reclamation, Tennessee Valley Authority, Soil Conservation Service, and Corps of Engineers. ${ }^{67}$ This exposure of the agencies' miscalculations is followed by a handsome disclaimer: $:^{88}$

The defects cited here are not intended to cast doubt upon the competence of the Federal agencies concerned with water development. Their integrity and the engineering qualifications of their personnel are not in question. Federal agencies have an enviable record for safe engineering design, and for successfully carrying out large engineering projects. They have been signally free of the taint of dishonesty in administering construction programs. Most of the blame must be placed on the lack of consistent national policies, and the absence of adequate provisions for review, inspection, and coordination of projects at Washington and basin levels.

Oddly enough, virtually this whole statement is repeated with specific respect to the Corps of Engineers when the Commission is dealing gingerly with flood-control

at id. at $3 \mathrm{x}$.

${ }^{05} \mathrm{I}$ id. at I2I.

00 I id. at 120 .

${ }^{\circ 7} \mathrm{I}$ id. at 20-25. But see Commissioner Holifield's criticism, in his dissent to the Commission's report. 2 id. at Io, $46-5$.

${ }^{88} \mathrm{x}$ id. at 25 . 
activities. Lest there be any doubt, the Commission adds, "The Commission wishes no sentence in the report to be construed as a reflection upon the Corps." In "deadpan" fashion, the Commission describes the organization of the Corps, noting without further comment that in late 1954, the Corps had II6 Army Engineers and 25,445 civilians assigned to the civil works program. The Commission thus refuses to draw the obvious conclusions from this ratio that were drawn both by the first Hoover Commission and by Albert L. Sturm in his impressive study of the Corps's case for retention of civil works activities-a study prepared for the second Hoover Commission's own task force. ${ }^{70}$

Proceeding to consider critically the Soil Conservation Service's headwater dam construction program, which "has raised many questions of conflict and overlap with the Corps of Engineers," the Commission formally recommends "that the construction of headwater dams in the flood control program of the Soil Conservation Service be transferred to the Corps of Engineers." This recommendation is arrived at "in view of the engineering competence of the Corps of Engineers and because its staff is operating in all streams of the country, and because another large engineering organization is undesirable in the Federal Government." ${ }^{\text {"1 }}$ So the net result of the Commission's consideration of the civil works role of the Corps is a recommendation for its enhancement.

We turn finally to the December 1955 report by the Presidential Advisory Committee on Water Resources Policy. ${ }^{72}$ The Committee consisted of Secretary of the Interior Douglas McKay (Chairman), Secretary of Agriculture Ezra Taft Benson, and Secretary of Defense Charles E. Wilson. The President established the Committee on May 26, r954, well aware that he already had the Bureau of the Budget, the President's Advisory Committee on Government Organization, and the second Hoover Commission available as potential alternative sources of at least organizational advice in the water resources field. However, he chose to set up the Cabinet Committee, with the Bureau and the Advisory Committee in cooperating roles, and with the relation to the Hoover Commission defined as one of the Committee's being prepared to assist in executive branch consideration and review of the Hoover Commission's recommendations, when submitted. As the Hoover Commission's report on water resources and power was submitted to Congress in June 1955, the Cabinet Committee had it and its related three-volume, r8oo-page task force report to draw on for information, points of view, and specific proposals. In the event, however, the Cabinet made no mention of any of its sources, and the degree of its

${ }^{80} \mathrm{x}$ id. at 67 .

${ }^{70}$ Albert L. Sturm, Civil Functions of the Corps of Engineers-Relation to Military Mission, 3 U.S. Comm'n on Organization of the Executive Branch of the Government, Task Force Repont on Water Resources and Power r473-r578 (1955). For the Task Force's own conclusions, sce I $i d$. at I90 et seq.

${ }^{71}$ I U.S. Comm'n on Organization of the Executive Branch of the Government, op. cit. shpra note 58 , at 70-7I.

${ }^{72}$ Presidential Advisory Coma. on Water Resources Policy, Water Resources Policy (1955). 
acceptance and rejection of Hoover Commission recommendations is, therefore, left for determination by those patient enough to compare the two reports.

The McKay Committee proposes four organizational creations: a Coordinator of Water Resources, a Board of Review for Water Resources Projects, a Federal Interagency Committee on Water Resources, and, at the regional or basin level, a series of water resources committees.

The Coordinator of Water Resources, located in the Executive Office of the President, would "provide Presidential direction to agency coordination and ... establish principles, standards, and procedures for planning and development of water resources projects." ${ }^{\text {33 }} \mathrm{He}$ would be permanent chairman of the Federal Interagency Committee on Water Resources, would cooperate with the Bureau of the Budget and the Council of Economic Advisors in evaluating departmental requests for appropriations, work with the Coordinator of Public Works Planning in relation to water resources developments, and assist in reconciling water resources policy with other federal policies. ${ }^{74}$ However, he would not assume the budgetary, fiscal policy review, or legislative clearance functions of the Bureau of the Budget.

The Board of Review for Water Resources Projects would also be in the Executive Office of the President. It would consist of three individuals, serving full-time, appointed by the President for terms corresponding to his own and serving at his pleasure, and, in now familiar terms, "should be chosen from qualified engineers, economists, or others of recognized abilities and judgment in the resources field."75 Although the reason for proposing creation of the Board is that "the President, before making final decision on water resources projects, should have the benefit of advice" of such a board, in operation, the Board would "report to the President through the Coordinator of Water Resources" and, in fact, address its recommendations, for the most part, to the Coordinator directly. The Board would have its own chairman, and the Coordinator would not be a member. ${ }^{76}$ Its terms of reference are variously phrased. It is "to analyze the engineering and economic feasibility of projects," "i7 to "evaluate, in the light of policy established by the Congress and criteria established by the Coordinator of Water Resources, all reports on water resources projects ...," to recommend any modifications "considered desirable from a comprehensive national viewpoint," and to recommend changes it deems advisable in the criteria for water resources projects. ${ }^{78}$

The Interagency Committee on Water Resources would be permanent, advisory in role, and chaired by the Coordinator already described. Its members would be the head or an assistant-secretary-rank official of the Departments of Agriculture, Army, Commerce, Health Education and Welfare, and Interior, and the Federal Power Commission. Advisory to the President, the Committee would be "the medium for coordination of the interrelated functions of the several agencies" and would "have authority by unanimous action to determine finally interagency relation-
${ }^{73}$ Id. at $\mathrm{xi}$.
${ }^{75} I d$. at 19.
${ }^{74} I d$, at 18 .
${ }^{77}$ Id. at xi.
${ }^{2}$ Ibid.
${ }^{78} I d$. at 19. 
ships." It would be "the channel for advice between the President and Federal representatives on the water resources committees"-to which we now turn. ${ }^{70}$

Each water resources committee at the regional or basin level would have a permanent, nonvoting chairman appointed by the President and would consist of one representative from each federal department having water resources responsibilities and one representative from each affected state, to be appointed by the governor. All members would be equal, but "the total number of either Federal or State representatives is regarded as immaterial, since the conflicts should be resolved by cooperation and not by voting strength." ${ }^{80}$ However, unresolved disagreements would be referred to the Coordinator of Water Resources. Each committee chairman would be responsible to the Coordinator and would have "a small independent staff and funds for independent use." 81

An inconspicuous footnote in the Cabinet Committee's report suggests that consideration might be given to broadening the scope of these committees to include all natural resources. Even under the name of "water resources committees," each is to prepare "a comprehensive plan which will best serve the region and the Nation in the development of water and related land resources." ${ }^{82}$ The committee would recommend an annual work schedule to be reflected in the budget requests of each cooperating agency and would report annually on progress.

A careful reading of the Cabinet Committee's description of these water resources committees leaves an impression of care to maintain the separate responsibility and vigor of the several national agencies with water resource interests. Every sentence in the following brief paragraph contributes to the full flavor: $:^{83}$

The water resources committees should be the principal and continuing medium through which the various departments, State and Federal, coordinate resources planning and development activities. The committees should serve as the mechanism through which the several agencies would prepare and publish joint plans for water resources development. Action on specific projects of joint plans, however, would be taken by the appropriate agency or agencies. The committee may foster studies of water resource problems not otherwise sponsored by any agency.

The concise report (a mere thirty-five pages) of the Cabinet Committee makes selection and summary almost impossible. Yet, the report itself is such a discrim. inating distillation of much of the thinking that has taken place about water resources administration that some characterization of the reasoning behind the recommendations must be attempted. The facts that the word "power" does not appear until page fourteen, and that one looks in vain for a mention of power development in the list of six objectives of "a sound water policy" ${ }^{44}$ need not deter one from seeking the report's wisdom on other matters. What may be thought of as the summary findings or conclusions of the Committee include two points of importance for administration.

\footnotetext{
70 Id. at $\mathrm{I} 8$.

${ }^{81}$ Id. at 18 .

${ }^{80}$ Id. at 17.

8s Ibid.

${ }^{82}$ Id. at 17.

${ }^{8 s}$ Id. at $\mathrm{xi}, \mathrm{I}$. For a somewhat different list, also omitting power, see $i d$. at 13 .
} 
"The greatest single weakness in the Federal Government's activities in the field of water resources development," says the Committee, "is the lack of cooperation and coordination of the Federal agencies with each other and with the States and local interests." ${ }^{\text {"S5 }}$ Largely to blame for this is the fact of "different laws empowering different agencies to pursue particular programs for different purposes."86 Second, the Committee believes that although planning the coordinated development of water resources by river basins is generally sound, it can be unduly emphasized, and the appropriate planning area, in some instances, may be the region, rather than the basin. ${ }^{87}$

Elsewhere, the Committee provides further foundation stones for the construction of effective water resources planning and development. Note the scope of the statement, "The objective of planning should be the best utilization of all water resources from the time precipitation falls upon the land until the water again finds its way into the sea," channel. A subtle point, of some administrative moment, is made in the recognition that most of the planning to date has been with respect to flood control, navigation, irrigation, soil conservation, watershed control, and hydroelectric power, at the expense of due concern for drainage, fish and wildlife preservation, recreation, scenic values, pollution control, and water supplies. ${ }^{89}$

The Committee finds that mere circulation for comment among interested agencies of the plans prepared by one agency is no answer to the need for coordination. A plan so prepared is "frequently lacking in the over-all viewpoint that should be controlling," point in their rather hurried efforts to consider the proposal. Nor would consolidation of "all Federal agencies engaged in natural resources development, including water . . . into a single Federal agency" be an effective solution, even apart from the question whether it would be adopted by Congress without a long delay. ${ }^{91}$ The problem is inconsistencies in policies, and a single agency responsible for all water resources development could not effectively operate until that problem was resolved.

The Committee's administrative proposals depend heavily upon the rigor with which its procedural views could be implemented. No agency would initiate an investigation of a major project without specific approval of Congress. No agency would have authority to proceed with any major project or program unless Congress had authorized it "by specific act of Congress for each such project." No agency would seek such authorization until its proposal had been reviewed for a reasonable time by the various federal departments, the Board of Review, the states, and local interests directly affected, nor until it had been cleared by the Coordinator of Water Resources. No agency would seek appropriations for an authorized project without re-examining the economics and engineering in a report that would be submitted

\footnotetext{
${ }^{86} I d$. at 2.

${ }^{87}$ Id. at 3 et seq.

${ }^{80} \mathrm{Id}$. at $\mathrm{I}_{3}$ et seq.

${ }^{01}$ Ilid.
}

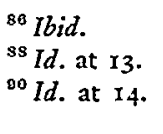


through the Bureau of the Budget to the Appropriations Committees: if significant economic or engineering changes had been made since the date of authorization, a report would have to be submitted to the Board of Review and then to the appropriate legislative (i.e., nonappropriations) committees of Congress for approval or modification of the project. If five years should elapse after a project had been authorized, with no funds appropriated for construction, the full review process would need to be fully repeated..$^{92}$

\section{IV}

\section{Conclusion}

The very fact that the choice of water resources projects is of political moment both complicates and simplifies our task. It complicates the task because a due respect for what is possible or impossible politically should lead one to modify his preferences for ideal administrative solutions. What Congress will accept then becomes the key question. If Congress will clarify its water resources policy, then administrative consolidation of water resources agencies becomes less necessary-such, at least, is one position. If Congress will interpose no objection to a presidential reorganization order that consolidates water resources agencies, then consolidation may be a tactical move directed toward eventually persuading Congress to reconcile its contradictory policies. If Congress will neither clarify its policies nor permit consolidation of agencies, then the immediately practical step is to strengthen coordination among water resources agencies in planning and in final processing of project proposals. These are all reasonable efforts to adapt administration to "the facts of life" on Capitol Hill.

Congress, however, will accept none of these solutions. It shows no disposition to clarify its policies, or, for that matter, to simplify its structure of committees concerned with water resources. ${ }^{93}$ It is even distrustful of administration efforts to standardize the methods by which the several agencies estimate economic and engineering feasibility of projects, lest congressional freedom of choice be thereby con-

${ }^{02} \mathrm{Id}$. at $28 \mathrm{et}$ seq.

${ }^{93}$ One of the most recent examples of awkward committee arrangements is the Watershed Protection and Flood Prevention Act of 1954, as amended in 1956. The Secretary of Agriculture is authorized to assist a local organization in constructing "works of improvement" having a total capacity not excceding 2500 acre-feet and involving a federal contribution of not over $\$ 250,000$. But "no appropriation shall be made for any plan" exceeding the acre-feet or dollar figures cited "unless such plan has becn approved by resolutions adopted by the appropriate committees of the Senate and House of Representativcs: Provided, That in the case of any plan involving no single structure providing more than 4000 acre-feet of total capacity the appropriate committees shall be the Committec on Agriculture and Forestry of the Senate and the Committee on Agriculture of the House of Represcntatives and in the case of any plan involving any single structure of more than 4000 acre-fect of total capacity the appropriatc committees shall be the Committee on Public Works of the Senate and the Committec on Public Works of the House of Representatives, respectivcly." 68 STAт. 666 (1954), as amended, 70 Stat. 1088, 16 U.S.C. $\$ 1002$ (Supp. III, 1956). Undoubtedly, the introduction of the Committes on Public Works was designed not only to protect their jurisdictional claims, but to protect the Corps of Enginecrs against undue trespass on its claimed jurisdiction by the Department of Agriculture. Sce Hearings before a Subcommittee of the Senate Committee on Public Works on H.R. 875o, Amending the Watershed Pro. tection and Flood Prevention Act, 84 th Cong., 2d Sess. (1956). 
stricted. ${ }^{94}$ It is opposed to consolidation of water resources agencies, and no recent President has dared to send to Congress a reorganization plan for this purpose. It is opposed to the strengthening of coordinative and review machinery in the Executive Office of the President. ${ }^{95}$

The retreat before congressional obduracy may halt with the discovery of the drainage basin committee formula for peace. Members of Congress are notably area-oriented and might find it easier to establish a kind of suzerainty over the committee for the basin from which they are elected ${ }^{96}$ than to work out a rewarding relation to a nationally-integrated water resources program developed in the Executive Office of the President. But to date, no organizational formula has been evolved for drainage basin committees that will satisfy the area orientation of congressmen, the national orientation of the President, and the functional orientation of the several water resources agencies.

Earlier confidence in interagency committees at the national and basin levels has evaporated. The second Hoover Commission's task force on water resources and power spoke in wholly disenchanted terms about the interagency committee device. Typically, each agency has an absolute veto; each representative on a committee is subject to reversal by higher officials in his own agency; each agency avoids criticism of a fellow agency lest the compliment be returned; the chairmanship is either held by one of the agencies or it rotates among the agencies (and either method is bad); the committee staff work is either farmed out to the agencies or is performed by an ad hoc staff assembled by detailing of personnel from the agencies (and again, either method is bad); and there is "the massive defect" of "the absence of formal, external control, and the fact that ... the agencies will be sitting in judgment on their own plans and actions."

os Bureau of the Budget, Cir. No. A-47, Reports and Budget Estramtes Relating to Federat. Programs and Projects for Conservation, Development, or Use of Water and Related Land Resources (1952) and the proposed revision of Nov. 29, 1954, was attacked in S. REs. 281, 84th Cong., $2 \mathrm{~d}$ Sess. ( $\left.195^{6}\right)$, and related hearings. Joint Hearings of the Senate Committees on Interior and Insular Affairs and on Public Works on S. Res. 28I, Conservation and Devclopment of Water Resources, 84th Cong., ad Sess. passim (1956).

${ }^{05}$ Robert E. Merriam, Assistant to the Director of the Budget, testified to the impasse on implementation of recommendations of the Presidential Advisory Committee on Water Resources Policy: "Then, too, I must say, Mr. Chairman, in all candor, that we discovered ourselves in this position: that as far as organizational matters are concerned, which is where the President's Advisory Committee thought it ought to start in its analysis of legislative proposals, we are faced with a situation, in which the chairmen of the two pertinent committees of the Senate ... have already indicated opposition to, as I understand it, at least 2 of the 3 specific organizational proposals that would require legislation, namely, that of a coordinator and a board of review." Id. at 64. Senator Murray earlier had commented on the President's Committee proposals: "It is manifest that the repetitive review which these processes would entail could succeed in bringing Federal participation in land and water-resources conservation and development to a complete standstill." Id. at 5 .

${ }^{\circ 0}$ The proposal of a Missouri Basin Commission emerged from the Missouri Basin Survey Commission, in which six of the eleven commissioners were members of Congress. The persistent efforts of Sen. Kenneth McKellar, of Tennessee, to establish patronage rights over the Tennessee Valley Authority, even though successfully resisted, are suggestive of congressional expectations about "their" constituency areas.

${ }^{07}$ I U.S. Comm'N on Organization of the Executtue Branch of The GovernMent, op. cit. supra note 7o, at 74. See also 3 id. at 1395-1472, for the excellent article, Vawter, Case Study of the Arkansas-White-Red River Basin Inter-Agency Committee. 
To be sure, there are ways of correcting many of these defects. But the corrections destroy the reasons for hope that Congress might accept basin committees, even if it will accept no other administrative solution. Any improvements in the interagency water resources committee must strengthen presidential control-through a chairman appointed by the President and affliated with none of the represented agencies, through the independent chairman's possession of determinative power in cases of disagreement within the committee (or power to refer disputes to the President's office), through provision of a staff and budget for the chairman, and through the vesting of final power to formulate the basin program in the President's office so that merely additive agreements among agencies may not come to take the place of truly integrated programs. Once this much is conceded, it seems impossible for the Presidency to avoid adding a national viewpoint that may relate each basin committee's program to those coming from other basin committees and so introduce a comprehensive national policy approach that will inevitably modify the results of the basin-oriented work.

There seems no reason to expect that Congress would welcome such an arrangement, for the President would again be forcing Congress to think of water resources development as a national program rather than as a disparate assemblage of specific projects in the districts of the individual congressmen.

The indications that Congress cannot be appeased by any administrative arrangement so far devised simplifies our immediate task of drawing conclusions about national water resources administration. Until further political analyses disclose a way in which Congress might accommodate the patent need for more reasonable arrangements for consideration of water resources programs, we can revert to relatively apolitical modes of analysis. In doing so, we may reopen questions that have been closed for several years in deference to the limits of what seemed possible.

The bulk of the planning, construction, and operation of water resources programs and projects should be in a single major national department. The civil functions of the Army Corps of Engineers, the headwater dams work of the Soil Conservation Service, and the irrigation and reclamation work of the Bureau of Reclamation should be consolidated in this department. Included in the department-presumably a reconstituted Department of the Interior-might well be certain other resource bases of economic development, particularly such energy sources as coal, oil, and gas. Nonetheless, even if the department embraces minerals and public lands, it cannot be a truly comprehensive department of natural resources, and the exclusion of atomic energy stands in the way of its achieving a total view of energy resources.

The emphasis upon water and upon construction of dams has obscured the fact that these are means, not ends. It follows that the planning of water resources projects must be oriented to policy judgments about ends to which water and construction projects can contribute. Although water and physical structures are strategic levers, control of which carries substantial influence on human welfare, the uses to which the levers shall be put must not be left to determination by staffs of 
construction engineers. Ultimately, the broad decisions must be made by Congress. But the decisions will be more rational if programs are formulated in the first instance in the executive branch.98

Water resource program formulation should be primarily the task of the secretarial level of the contemplated department, and something comparable to the Interior Department's Program Staff of the pre-r953 period should aid the secretary in this responsibility. ${ }^{99}$ Both the secretary and the program staff will do a betterrounded job if the department includes several resources (and even resource uses, such as recreation and commercial fishing), for the planning problem is not water, but the relation of water to other resources and to human needs, and the programmers need constantly to be reminded of this within their own department.

To build up the department secretary's role would proportionately relieve the pressure on the Presidency, and so reduce the tendency to multiply various coordinative and "objective" boards and committees in the Executive Office. The latter tendency has been prominent in recent official reports and suggests a too easy dumping of problems into the President's office.

A distinction needs to be drawn between water resources development and economic development. The latter, it has been suggested earlier, is a far broader concept and involves a much greater variety of elements than does water resources development. Administratively, this warrants recognition by different organizational levels. Responsibility for economic planning might be placed in the Executive Office of the President, while responsibility for water resources planning might rest with the secretary of the proposed department. This does not mean that water resources programs formulated in the department should not be reviewed in the President's office before transmittal to Congress. It does mean that the review should be broad in nature.

Decentralization of initial drafting of water resources programs to the drainage basin level should be easier to manage within a single department than would be an attempt to vest a presidential basin representative with authority to direct field agents of several national agencies. And it would certainly be more effective than would be loose-jointed cooperation through interdepartmental committees. Decentralization of initial preparation of economic development programs, on the other hand, might well follow regional, rather than basin, lines and might need to draw on a number of agencies through interdepartmental committees, temporary assemblage of joint staffs, and assignment of individual research projects. Our experience to date indicates that reports on regional economic development are likely to be informing and suggestive, but not to be firm plans or programs that will be formally adopted by the President or Congress. "Hard" planning of water resources programs and

${ }^{88}$ The ideal conception of the relation between formulation by the executive branch and decision by Congress calls for the formulation of, say, three alternative programs costing different amounts; thereby Congress would actually choose, instead of merely ratify.

${ }^{00}$ See Wengert and Honey, Program Planning in the U.S. Department of the Interior, 1946-53, 14 Pub. Admin. Rfv, 193 (1954). 
"soft" planning of economic development are, therefore, likely to raise different administrative questions, or at least to raise the same questions with different intensities.

These reflections do not resolve the problems of administrative organization raised in the early pages of this paper. The neat categories of administrative logic are seldom exactly reproduced in the untidy world of administrative reality. But certain marginal gains may be anticipated from action along the simple lines suggested. The reconstituted Department of the Interior would be oriented nationally, instead of westerly. 'This is in part because absorption of the Corps of Engineers' civil functions would bring into this department the rivers and harbors-dredging and the flood-control activities of the East and South. It is in part, too, because a clearlyidentified administrative center for water resources programming would predictably concern itself with the increasingly urgent water problems of heavily-populated and industrialized sections of the country. If the department were oriented in this fashion, certain other pieces of the puzzle would fall into place.

A nationally-oriented department, with a well-integrated objective whose accomplishment is substantially compatible with the public interest, may, with some luck, become a worthy possessor of responsibilities that otherwise would have to be retained in the President's office. That is, a department that is concerned solely with a particular section of the country, or a particular resource, or a particular use of a resource (e.g., irrigation, power) is in the role of a biased advocate, and its proposals must be carefully evaluated at a higher level where a broader perspective prevails; but if these identifications of interest can be expanded, a broad perspective may be hoped for at the departmental level. This, it is true, will not follow unless the programming responsibility is kept at the secretary's level. If it is shifted to the bureau level, there may follow a segmentation of interests, a narrowed perspective on the public interest, a tendency to find satisfaction in energetic pursuit of limited objectives; the building of dams is more likely to become an end in itself, and engineers are more likely to be making policy judgments beyond their ken.

Within this framework, there would appear to be room for two other developments. One is the working out of the conflict between areal and functional bases of organization, which underlies much of the difficulty surrounding the idea of basin committees or basin staffs. The other is the encouragement of congressional attitudes that may lead to a programmatic approach to authorization and appropriation for water resources projects, a development of consistent policies, and a reconsideration of the present jurisdictional divisions among the Public Works, Agriculture, and Interior and Insular Affairs Committees. Both developments would be advanced by a redesigned Interior Department.

To go beyond this point of reflection and prediction one has need of "An eye that like a diver to the depth / Of dark perplexity can pass and see, / Undizzied, 
unconfused."100 He who possesses such an eye might cast his gaze on the political obstacles to improvement of water resources administration. ${ }^{101}$

100 Aeschylus, The Supplinist, in I Whitney J. Oates and Eugene O'Neill, Jr., The Complete Greer Drama 22 (1938).

${ }^{103}$ The focus should perhaps be stated somewhat differently. We now have a number of admirable descriptive accounts of political obstacles. See Arthur Manss, Muddy Waters: The Armx Engmeers and the Natton's Rivers (i95i); Norman Wengert, Natural Resources and the Polittcat Struggle (1955); VINCENT OSTROM, WATER AND Politics (1953). What we lack is a discerning analysis of ways to emerge from the long-standing political impasse. 